\title{
Welfare Status and Type of Floor Associated with Hock Lesions in Dairy Cattle of University, Research and Private Farm of Chitwan District.
}

\author{
R. Jha*1, Y.B. Gurung ${ }^{2}$, D.K. Singh ${ }^{3}$ \\ ${ }^{1}$ Institute of Agriculture and Animal Science (IAAS), TU \\ ${ }^{2,3}$ Department of Pathology and Clinics, IAAS, TU \\ *Corresponding author: ritikesh1@gmail.com
}

\begin{abstract}
This research is an investigation of the prevalence of, and factors associated with, hock lesions on dairy cattle of University, Research and Private farm of Chitwan district. Cemented floor (n =141), Muddy floor (27), Floor with Mat (35) and brick paved floored animals ( $n=33)$ were visited. Cows were scored for hock (tarsus) lesions on a 3 point scale combining the attributes ofhair loss, broken skin, and swelling. Type of farm (University, Research and Private) and type of floor measures were taken which were hypothesized to be risk factors for lesions. On university $(A F U)$, research (NARC) and private farms the mean level prevalence of hock lesions was $1.827 \pm 0.384,1.4 \pm 0.4905$ and $1.465 \pm 0.68$ respectively. On cemented floor, muddy floor, floor with rubber mat and brick paved floor, the mean prevalence of hock lesions was $1.63 \pm 0.489,1.0165 \pm 0.577,1.343 \pm 0.481$ and $1.83 \pm 0.44$ respectively. In conclusion muddy floor was associated with reduced hock lesions scoring compared to cemented, brick and rubber mat
\end{abstract}

Keywords: Hock lesion score, Welfare, Floor types

\section{INTRODUCTION}

Intensive farming systems are now common practice to meet the increasing demand for milk in different parts of the world. This has led to the introduction of dairy cows to an environment arbitrarilydifferent from the cows' natural habitat, thereby triggering a range of welfare consequences. An animal is said to be in good welfare when it is able to express its innate behavior, free from distress and fear, in the absence of pain, and in good health (Duncan and Fraser, 1997). However, these fundamentals of optimal welfare are often lacking with the advent of confining cows and persistent demands for high milk yield. As a result of these practices, outcomes such as chronic pain, discomfort, increased susceptibility to infectious disease and metabolic or physical fatigue are now common in dairy cows within intensive farming systems (Cook et.al., 2016). Lameness is a multifactorial condition and the most important welfare problem in dairy cows. Lameness is also regarded as a cause of economic loss owing to a reduction in milk yields, lowered reproductive performance and an increased risk of culling (Sogstad et.al., 2006). Farmers are often reported to underestimate the prevalence of lameness, thereby prompting a low perception of its impact on cow welfare, health and production (Horseman et.al., 2016). With the rising occurrence of lameness in dairy herds globally, attempts to reduce the impact on welfare and production are needed. However, certain animal-based measures such as body condition scoring (BCS), hock condition and leg hygiene have been employed in assessing cow welfare, with recent findings suggesting vital associations 
with lameness.Poor hock condition have been reported to have a higher likelihood of becoming lame (Randall et.al. 2015). Housing design is vital for the maintenance of good welfare in dairy cows. Floor type and its influence on locomotion performance in dairy cattle were first suggested by Albright in 1997. Subsequently, floor features such as abrasiveness and hardness leading to insufficient friction and traction - as present in concrete floors (CF)were suggested to negatively impact the claw health and locomotion of dairy cows (Van der Tol et.al., 2005).

Although claw lesions remain among the major causes of lameness in dairy cows (Manske et.al., 2002), hock lesionsand injuries are becoming a persistent problem in intensively managed dairy farms (Zaffino et.al., 2014). The term "hock lesion" is used to describe various anomalies such as hair loss, visible wounds, broken skin, and localized and general swelling of the hock (Kielland et.al., 2009). In dairy cows, the absence of fatty tissues and muscles around the hock makes the region prone to trauma and damage to the skin. Consequently, the development of hock lesions is directly influenced by the nature of the lying surface of hard and abrasive (Kester et.al., 2014). In welfare assessment, the lateral aspect of the hock is often examined and suggested to be the most affected area. Poor hock conditions are often manifested as hair loss, swelling or ulceration (Potterton et.al., 2011).

The hock condition score (HCS) measures the severity of hock lesions on various scoring scales based on features ranging from normal to substantial injuries. The assessment is important in free-stalls and loose cubicle housing, as such provisions encourage movement and interaction with stall designs. This makes it important to investigatethe dairy animals for hock lesions and associated risk factors under field conditions. Keeping this inmind the present study was designed todetermine the incidence of hock lesions as Welfare status inthe study area andtype of floor associated with hock lesions in dairy cattle of University, Research and Private farm of Chitwan district.

\section{METHODOLOGY}

The present study was carried out in Chitwan District, Nepal during December 2015 to May 2016. Majority of farmers and university and research farm in thestudy area were rearing Holstein Friesian (HF) crossbred and Jersey crossbred dairycattle. Number of animal maintained perhousehold was two to five mature cows along with their progenies. Number of animals maintained at research (NARC) farm and university farm (AFU) was 71 and 29 respectfully. The floor type in university farm was completely cemented where as in research farm, it was in combination of mat and cemented. However in private farm it was in combination of brick, mud and cemented floor. Therefore, all the mature animals were investigated for once during the study period to determinethe incidence of hock lesions and floor types associated with incidence of hock lesions by recording of animal level andfarm level factors associated with hock lesions using standard observation methods. A total of 250 crossbred dairy cattle were investigatedduring the study period regardless of theirlactation status.

Hock lesions scoring was assessedusing a 3 point ordinal scale where1 scores (fig.1) were consideredclinically normal hocks, 2 (fig. 2) with skin loss and 3 (fig. 3) with swelling and ulceration scores (Lombard et.al., 2010). The floor type which was prevalent in area were categorized into cemented, muddy, rubber mat and brick paved. 


\section{Statistic}

Data obtained was entered in MS Excel 2007and then loaded into OpenEpi software. Basic descriptiveanalysis was done and the ANOVAwas performed to find out the association among various type of farms and various types of floor associated with thehock lesions. A $p$ value less than 0.05 wasconsidered significant.

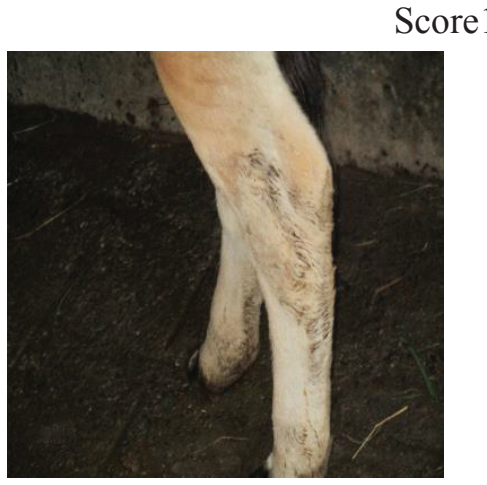

Fig-1

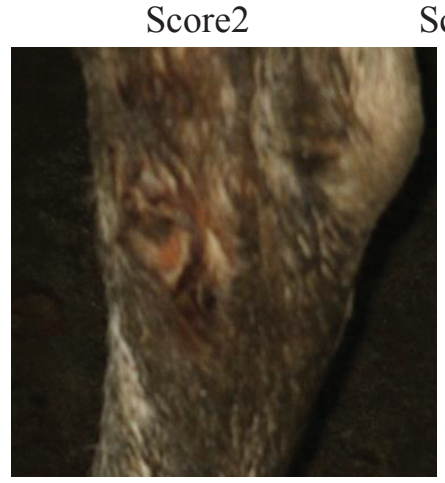

Fig-2
Score3

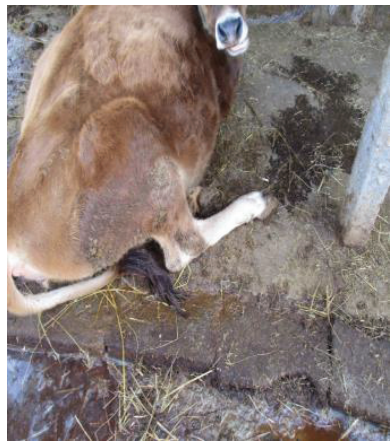

Fig-3

\section{RESULT}

Results are shown in table 1 and table 2. The average hock lesions score in university farm was significantly higher in comparison to research and private farm. Although non-significant the hock lesion score was less in muddy floor as compare to cemented, brick paved and rubber mat floor.

Table 1. Overall distribution of mean hock lesion score with S.D. among different types of farm.

\begin{tabular}{|l|l|l|}
\hline Type of Farm & Number & Mean hock lesions score \pm S.D. \\
\hline University (AFU) & 29 & $1.827 \pm 0.384$ \\
\hline Research (NARC) & 71 & $1.4 \pm 0.905$ \\
\hline Private farm & 150 & $1.465 \pm 0.68$ \\
\hline
\end{tabular}

P-value $=0.00168295$.

Table 2. The overall distribution of mean hock lesion score with S.D. among different types of floor.

\begin{tabular}{|l|l|l|}
\hline Type of Flooring & Number & Mean Hock lesion score \pm S.D. \\
\hline Cemented & 141 & $1.63 \pm 0.489$ \\
\hline Mud & 27 & $1.0165 \pm 0.577$ \\
\hline Rubber Mat & 35 & $1.343 \pm 0.481$ \\
\hline Brick Paved & 33 & $1.83 \pm 0.44$ \\
\hline
\end{tabular}

$\mathrm{P}$-value $=0.525189$ 


\section{DISCUSSION}

Our research showed that university livestock farm having more hock lesion score compared to research and private farm. It might be due toprolonged standing and walking on hard or abrasive surfaces in university farm. At research farm although animals are also maintained on cemented floor but some animals are maintained on rubber mat. At private farm the animals are maintained on combination of cemented, brick and muddy floorthat might results into less hock lesion score compared to university farm. From our results it has been shown that less hock lesion score, when animals are maintained on muddy floor. Fjeldaas et.al., (2011) reported that the risk of higher lameness score (LS) was three times higher in cows on cemented floor (CF) compared to rubber floor (RF). Several studies have demonstrated the inter-relationship between occurrence of hock lesions and lameness in dairy cow (Cook et.al., 2016, Whay et.al., 2002, Rutherford et.al., 2009).

The level of comfort from the lying surface might influence the severity of hock lesions as well as increase the risk of lameness (Brenninkmeyer et.al. 2013). Hence, the pathogenesis of hock lesions and the direction of the event as related to lameness need to be investigated. Severe hock lesions could initiate painful sensations leading to lameness, while a prolonged duration of lying down in lame cows on hard and abrasive surfaces might precipitate hock injuries. Another aspect that might contribute to the occurrence of severe hock injury is floor slipperiness.A recent study reported higher odds (Odds ratio, $\mathrm{OR}=2.0$ ) of cows being lame and with hock lesions $(\mathrm{OR}=$ 1.4) when reared on slippery floors compared to non-slippery floors (Solano et.al., 2015). Telezhenko et.al. (2017), in a recent study involving gait analysis and skid resistance of different flooring systems in dairy housing, showed that rubber mats had the highest coefficient of friction and skid resistance values compared to concrete and mastic asphalt floors. This further depicts lower slipping tendencies in cows when housed on rubber mats or floors.Our observation also showed that university farm having dungs soiled cemented floor which become slippery that might lead to more hock lesions score.

Overall, aforementioned events and our results show that preventive measures for hock lesions have the potential of reducing lameness incidencecontributing to general improvements in cow welfare.Mostafa and Maharan (2016) have reported higher hock injury in atie stall barn with concrete floor $(11.9 \%)$. Higher hock injury in the tie-stall barn can beattributed to confinement of the animal at oneplace due to which their movements areconfined which have an effect on hock injuryand may be the reason behind more stress onhock in tie-stall barns.

\section{CONCLUSION}

Our researchshowed that muddy floor produce less hock lesion score compared to cemented, rubber mat, and brick paved floor in dairy animals. 


\section{REFERENCE}

Brenninkmeyer, C.; Dippel, S.; Brinkmann, J.; March, S.; Winckler, C.; Knierim, U. (2013). Hock lesion epidemiology in cubicle housed dairy cows across two breeds, farming systems and countries. Prev. Vet. Med., 109, 236-245. [Cross Ref] [PubMed]

Cook, N.B.; Hess, J.P.; Foy, M.R.; Bennett, T.B.; Brotzman, R.L. (2016). Management characteristics, lameness, and body injuries of dairy cattle housed in high-performance dairy herds in Wisconsin. J. Dairy Sci., 99, 5879-5891. [Cross Ref] [PubMed]

Cook, N.B.; Hess, J.P.; Foy, M.R.; Bennett, T.B.; Brotzman, R.L. (2016). Management characteristics, lameness, and body injuries of dairy cattle housed in high-performance dairy herds in Wisconsin. J. Dairy Sci., 99, 5879-5891. [Cross Ref] [PubMed]

Duncan, I.J.H.; Fraser, D. (1997). Understanding animal welfare. In Animal Welfare; Appleby, M.A., Hughes, B.O., Eds.; CABI Publishers: Wallingford, UK,; pp. 19-31.

Fjeldaas, T.; Sogstad, A.M.; Osteras, O. (2011). Locomotion and claw disorders in Norwegian dairy cows housed in freestalls with slatted concrete, solid concrete, or solid rubber flooring in the alleys. J. Dairy Sci., 94, 1243-1255. [Cross Ref] [PubMed]

Horseman, S.V.; Roe, E.J.; Huxley, J.N.; Bell, N.J.; Mason, C.S.; Whay, H.R. (2014). The use of in-depth interviews to understand the process of treating lame dairy cows from the farmer's perspective. Anim. Welf., 23, 157-165. [Cross Ref] Randall, L.V.; Green, M.J.; Chagunda, M.G.; Mason, C.; Archer, S.C.; Green, L.E.; Huxley, J.N. (2015). Low body condition predisposes cattle to lameness: An 8-year study of one dairy herd. J. Dairy. Sci., 98, 3766-3777. [Cross Ref] [PubMed]

Kester, E.; Holzhauer, M.; Frankena, K. (2014). A descriptive review of the prevalence and risk factors of hock lesions in dairy cows. Vet. J., 202, 222-228. [Cross Ref] [PubMed] Potterton, S.L.; Green, M.J.; Harris, J.; Millar, K.M.; Whay, H.R.; Huxley, J.N. (2011).Risk factors associated with hair loss, ulceration, and swelling at the hock in freestall-housed UK dairy herds. J. Dairy Sci., 94, 2952-2963. [Cross Ref] [PubMed]

Kielland, C.; Ruud, L.E.; Zanella, A.J.; Osteras, O. (2009). Prevalence and risk factors for skin lesions on legs of dairy cattle housed in freestalls in Norway. J. Dairy Sci., 92, 54875496. [CrossRef] [PubMed]

Manske, T.; Hultgren, J.; Bergsten, C. (2002). Prevalence and interrelationships of hoof lesions and lameness in Swedish dairy cows. Prev. Vet. Med., 54, 247-263. [Cross Ref]

Mostafa, A.S and Mahran, H.A. 2016. Assessment of welfare and health of dairy cows under different housing and management systems. Journal of Applied Veterinary Sciences. 1, 57-69.

Rutherford, K.M.; Langford, F.M.; Jack, M.C.; Sherwood, L.; Lawrence, A.B.; Haskell, M.J. (2009). Lameness prevalence and risk factors in organic and non-organic dairy herds in the United Kingdom. Vet. J., 180, 95-105. [Cross Ref] [PubMed]

Sogstad, A.M.; Osteras, O.; Fjeldaas, (2006). T. Bovine claw and limb disorders related to reproductive performance and production diseases. J. Dairy Sci., 89, 2519-2528. [Cross Ref]

Solano, L.; Barkema, H.W.; Pajor, E.A.; Mason, S.; LeBlanc, S.J.; ZaffinoHeyerhoff, J.C.; Nash, C.G.; Haley, D.B.; Vasseur, E.; Pellerin, D.; et al. (2015). Prevalence of lameness and associated risk factors in Canadian Holstein-Friesian cows housed in freestall barns. J. Dairy Sci., 98, 6978-6991. [Cross Ref] [PubMed] 
Telezhenko, E.; Magnusson, M.; Bergsten, C. (2017). Gait of dairy cows on floors with different slipperiness. J. Dairy Sci., 100, 6494-6503. [Cross Ref] [PubMed]

Van der Tol, P.P.; Metz, J.H.; Noordhuizen-Stassen, E.N.; Back, W.; Braam, C.R.; Weijs, W.A. (2005). Frictional forces required for unrestrained locomotion in dairy cattle. J. Dairy Sci., 88, 615-624. [Cross Ref]

Whay, H.R.; Main, D.C.J.; Green, L.E.; Webster, A.F.J. (2002). Farmer perception of lameness prevalence. In Proceedings of the 12th International Symposium on Lameness in Ruminants, Orlando, FL, USA, 9-13 January 2002; pp. 355-358.

ZaffinoHeyerhoff, J.C.; LeBlanc, S.J.; DeVries, T.J.; Nash, C.G.R.; Gibbons, J.; Orsel, K.; Barkema, H.W.; Solano, L.; Rushen, J.; de Passillé, A.M.; et al. ( 2014). Prevalence of and factors associated with hock, knee, and neck injuries on dairy cows in freestall housing in Canada. J. Dairy Sci., 97, 173-184. [Cross Ref] [PubMed] 